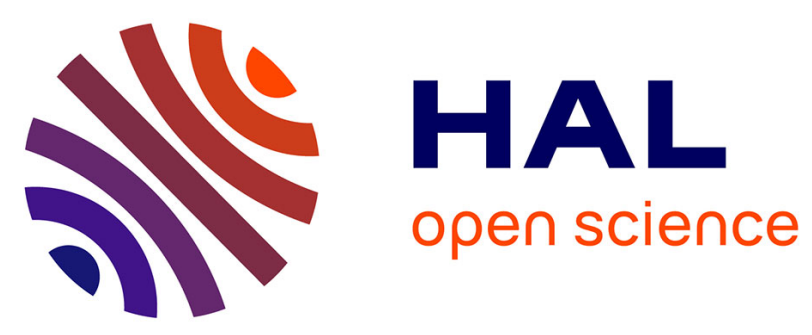

\title{
The Behavior of $\mathrm{Cp}^{*} \mathrm{MoBr} / \mathrm{Br} 2$ Redox Systems: The Unusual Structure of [(Cp*2Mo2Br4)2(Cp*MoBr4)3], a Compound Containing MoIII, MoIV, and MoV
}

\author{
Jahanvi Desai, John Gordon, Heinz-Bernhard Kraatz, Beth \\ Owens-Waltermire, Rinaldo Poli, Arnold Rheingold
}

\section{To cite this version:}

Jahanvi Desai, John Gordon, Heinz-Bernhard Kraatz, Beth Owens-Waltermire, Rinaldo Poli, et al.. The Behavior of $\mathrm{Cp} * \mathrm{MoBr} / \mathrm{Br} 2$ Redox Systems: The Unusual Structure of [(Cp*2Mo2Br4)2(Cp*MoBr4)3], a Compound Containing MoIII, MoIV, and MoV. Angewandte Chemie International Edition, 1993, 32 (10), pp.1486-1488. 10.1002/anie.199314861 . hal-03533373

\section{HAL Id: hal-03533373 https://hal.science/hal-03533373}

Submitted on 18 Jan 2022

HAL is a multi-disciplinary open access archive for the deposit and dissemination of scientific research documents, whether they are published or not. The documents may come from teaching and research institutions in France or abroad, or from public or private research centers.
L'archive ouverte pluridisciplinaire HAL, est destinée au dépôt et à la diffusion de documents scientifiques de niveau recherche, publiés ou non, émanant des établissements d'enseignement et de recherche français ou étrangers, des laboratoires publics ou privés. 
The Behavior of $\mathrm{Cp}^{*} \mathrm{MoBr} / \mathrm{Br}_{2}$ Redox Systems: The Unusual Structure of $\left[\left(\mathrm{Cp}_{2}^{*} \mathrm{Mo}_{2} \mathrm{Br}_{4}\right)_{2}\left(\mathrm{Cp}^{*} \mathrm{MoBr}_{4}\right)_{3}\right]$, a Compound Containing $\mathrm{Mo}^{\mathrm{III}}, \mathrm{Mo}^{\mathrm{IV}}$, and $\mathrm{Mo}^{\mathrm{V} * *}$

By Jahanvi U. Desai, John C. Gordon, Heinz-Bernhard Kraatz, Beth E. Owens-Waltermire, Rinaldo Poli, ${ }^{*}$ and Arnold L. Rheingold

There is considerable interest in the use of cyclopentadienyl transition metal complexes having one or more halo ligands as convenient starting materials for the synthesis of a large variety of organometaliic compounds. ${ }^{[1]}$ Although complexes of the group 6 metals molybdenum and tungsten are well known for the II and $\mathrm{v}$ oxidation state, $\mathrm{Mo}^{\mathrm{IV}}$ and $\mathrm{W}^{\mathrm{IV}}$ complexes have received little attention. Only recently, we were able to obtain $\left[\mathrm{CpMoCl}_{3}\right]\left(\mathrm{Cp}=\eta^{5}-\mathrm{C}_{5} \mathrm{H}_{5}\right)$, an insoluble powder and presumably an oligomer ${ }^{[2]}$ In order to obtain complexes that lend themselves to structural characterization, we have moved to the more soluble $\mathrm{Cp}^{*}$ complexes $\left(\mathrm{Cp}^{*}=\eta^{5}-\mathrm{C}_{5} \mathrm{Me}_{5}\right)$. We report here on the synthesis and highly unusual crystal structure of $\mathbf{1}$.

$\left[\left\{\left[\mathrm{Cp} * \mathrm{Mo}(\mu-\mathrm{Br})_{4} \mathrm{MoCp}^{*}\right]^{+}\left[\mathrm{Cp}^{*} \mathrm{MoBr}_{4}\right]^{-}\right\}_{2}\right]\left[\mathrm{Cp}^{*} \mathrm{MoBr}_{4}\right] \quad 1$

This compound is novel in that it is 1) the first known tetrabromo-bridged $\mathrm{d}^{2}-\mathrm{d}^{3}$ dimer, 2) the first $\mathrm{d}^{2}\left[\mathrm{Cp} * \mathrm{MX}_{4}\right]^{-}$ complex to be structurally characterized, and 3) the first neutral $\mathrm{Mo}^{\mathrm{v}}$ tetrabromide to be structurally characterized. In addition, molybdenum is found in three different oxidation states in the same crystal. This is possible because of the particular redox properties of the $\mathrm{Cp} * \mathrm{MoBr} / \mathrm{Br}_{2}$ system which we will describe here. Complex 2 has been prepared from $3^{[3]}$ and sodium amalgam in toluene as a diamagnetic

$\left[\mathrm{Cp}^{*} \mathrm{Mo}(\mu-\mathrm{Br})_{4} \mathrm{MoCp} *\right] \quad 2 \quad\left[\mathrm{Cp}^{*} \mathrm{MoBr}_{4}\right] \quad 3$

[*] Prof. R. Poli, J. U. Desai, Dr. J. C. Gordon, Dr. H.-B. Kraatz

Department of Chemistry and Biochemistry

University of Maryland

College Park, MD 20742 (USA)

Telefax: Int. code + (301)314-9121

Dr. B. E. Owens-Waltermire, Prof. A. L. Rheingold

Department of Chemistry, University of Delaware (USA)

$\left[{ }^{* *}\right]$ This research was supported by the U.S. Department of Energy - Office of Energy Research (grant no. 92ER14230). R. P. is a Presidential Young Investigator (1990-1995), an Alfred P. Sloan Research Fellow (19921994), and an Alexander von Humboldt Research Fellow (1993-1994). 
crystalline complex, which is isostructural to the neutral $\left(\mathrm{d}^{3}-\mathrm{d}^{3}\right)$ complex $\left[\mathrm{Cp}^{\prime} \mathrm{Mo}(\mu-\mathrm{Br})_{4} \mathrm{MoCp}^{\prime}\right] \quad\left(\mathrm{Cp}^{\prime}=\eta^{5}-1-(2,5-\right.$ dimethoxyphenyl $)-2,3,4,5$-tetraphenylcyclopentadienyl $)^{[4]}$ and to [ $\left.(i \mathrm{Pr}) \mathrm{CpMo}(\mu-\mathrm{Cl})_{4} \mathrm{MoCp}(i \mathrm{Pr})\right] .^{[5]}$ The unit cell of $2^{[6]}$ contains two independent molecules, one located at an inversion center and the second one in a general position. The two crystallographically independent molecules are chemically equivalent and can be described as two four-legged piano stool structures sharing a common square face defined by the four bridging bromo ligands (Fig. 1). Complex 2 undergoes two reversible one-electron oxidations at $E=-0.30 \mathrm{~V}$ and $+0.73 \mathrm{~V}$ (vs. ferrocene)

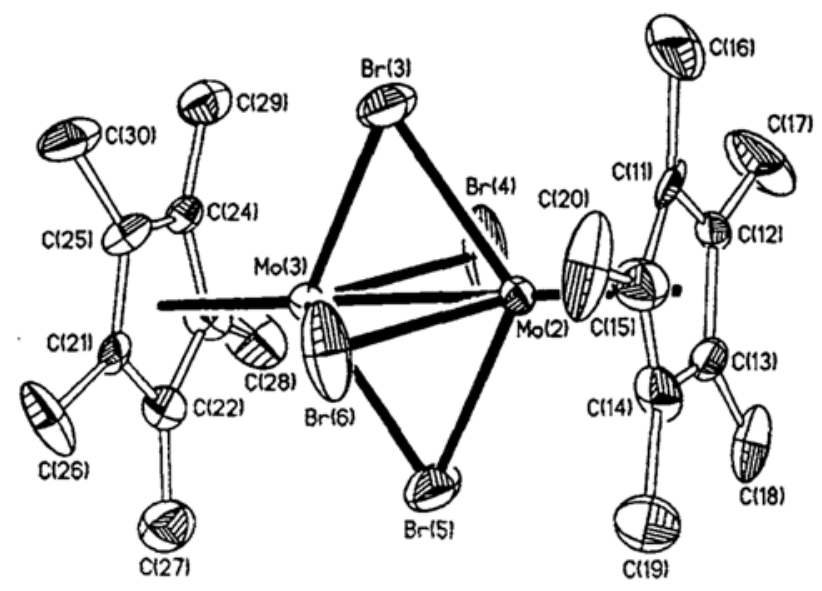

Fig. 1. Crystal structure of 2 (ORTEP plot shows the molecule in a general position). The geometry is identical to that of the molecule located at an inversion center in 2 and also to that in cation $2^{+}$. Selected bond lengths $[\AA]$ and angles [ ] (averaged over all chemically equivalent groups of atoms): 2 : Mo-Mo 2.643(2). Mo-Br 2.613(9); Mo-Br-Mo 60.8(3). 2+ : Mo-Mo 2.643(5) Mo-Br 2.64(3); Mo-Br-Mo 60.0(8).

In an attempt to prepare 4 by bromination of 2 with $\mathrm{Br}_{2}$ (mol ratio 1:1) in benzene, we obtained a brick-red precipitate (5), which analyzes as $\mathrm{Cp} * \mathrm{MoBr}_{3.3}$ and shows a single

$\left[\left\{\mathrm{Cp}^{*} \mathrm{MoBr}_{3}\right\}_{2}\right] \quad 4 \quad\left[\left\{\mathrm{Cp}_{2}^{*} \mathrm{Mo}_{2} \mathrm{Br}_{4}\right\}\right]^{+}\left[\mathrm{Br}, \mathrm{Br}_{3}\right]^{-} \mathbf{5}$

broad resonance at $\delta=4.3 \mathrm{in}$ its ${ }^{1} \mathrm{H}$ NMR spectrum in CD$\mathrm{Cl}_{3}$. This resonance is identical to that of the product obtained upon treatment of 2 with one equivalent of $\mathrm{AgBF}_{4}$. Thus $\mathbf{5}$ is interpreted as being a salt of $\left[\mathrm{Cp}^{*} \mathrm{Mo}(\mu\right.$ $\left.\mathrm{Br})_{4} \mathrm{MoCp} *\right]^{+}\left(2^{+}\right)$, and its anion is presumably a $1: 4$ mixture of $\mathrm{Br}^{-}$and $\mathrm{Br}_{3}^{-}$. According to our electrochemical investigations and the literature, ${ }^{[7]} \mathrm{Br}_{2}$ does not have sufficient oxidizing power to produce the dication $2^{2+}$ (see Fig. 2).

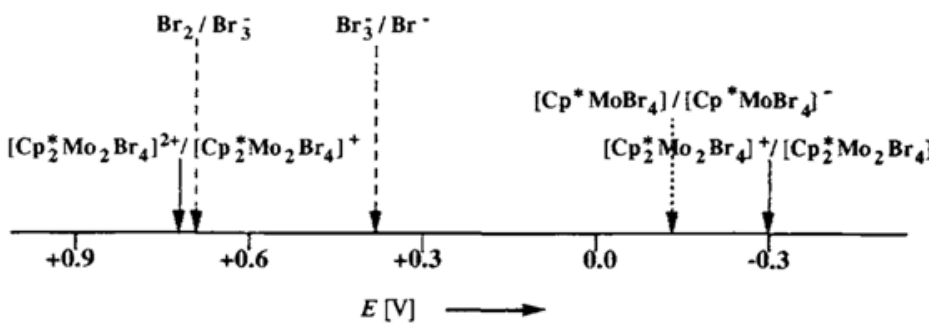

Fig. 2. Electrochemical behavior of the $\left[\mathrm{Cp}_{2}^{*} \mathrm{Mo}_{2} \mathrm{Br}_{4}\right]^{n+},\left[\mathrm{Cp}^{*} \mathrm{MoBr}_{4}\right]^{n-}$, and $\mathrm{Br}_{2} / \mathrm{Br}_{3}^{-} / \mathrm{Br}^{-}$systems.
Recrystallization of 5 from $\mathrm{CH}_{2} \mathrm{Cl}_{2} / n$-heptane yielded the title compound $\mathbf{1}$ as a dark red, crystalline material, which is paramagnetic and displays two broad peaks at $\delta=4.2$ and -19.5 in its ${ }^{1} \mathrm{HNMR}$ spectrum. The resonance at $\delta=-19.5$ is assigned to the anion $\left[\mathrm{Cp}^{*} \mathrm{MoBr}_{4}\right]^{-}\left(3^{-}\right)$(vide infra). The cyclic voltammogram of 1 shows, in addition to the two reversible one-electron oxidations characteristic of $\mathbf{2}$, a reversible wave at $E=-0.14 \mathrm{~V}$ (vs. ferrocene), which is due to the $\left[\mathrm{Cp} * \mathrm{MoBr}_{4}\right]^{0} /\left[\mathrm{Cp} * \mathrm{MoBr}_{4}\right]^{-}$couple as shown by an independent study of $\mathbf{3}$ (Fig. 2). A comparison of the oxidation potentials in Figure 2 indicates that 1 consists of the mixed-valence cation $\left[\mathrm{Cp}^{*} \mathrm{Mo}(\mu-\mathrm{Br})_{4} \mathrm{MoCp}\right]^{+}$and a $2: 1$ mixture of the anion $\left[\mathrm{Cp}^{*} \mathrm{MoBr}_{4}\right]^{-}$and the corresponding $\mathrm{Mo}^{\mathrm{v}}$ neutral analogue. This rules out the alternative formulation of 1 as a $1: 1$ mixture of monocation and dication for the dinuclear complex accompanied by three negatively charged mononuclear complexes.

Compound 1 crystallizes in the monoclinic space group $P 2_{1} / m$ with two formula units per unit cell. ${ }^{[8]}$ The dinuclear monocation $2^{+}$is located in a general position, and its structure is practically identical to that of the neutral precursor 2 (Fig. 1). According to theoretical considerations, ${ }^{[9]}$ the HOMO of 2 should be nonbonding. This explains the little change in the Mo-Mo separation upon oxidation ( $d(\mathrm{Mo}-$ Mo) : $\mathbf{2}=2.645(2) \AA ; \mathbf{2}^{+}=2.691(4) \AA$ ). This is the first direct comparison of metal-metal distances in a pair of $\left[\left\{\mathrm{CpMX}_{2}\right\}_{2}\right]^{n+}$ complexes and experimentally confirms the theoretical predictions by Green et al ${ }^{[9]}$ The two $\mathrm{Mo}^{\mathrm{IV}}$ anions $3^{-}$and the neutral $\mathrm{Mo}^{v}$ complex 3 are located on mirror planes. These all have the familiar four-legged piano stool structure (Fig. 3). The bond angles are not significantly

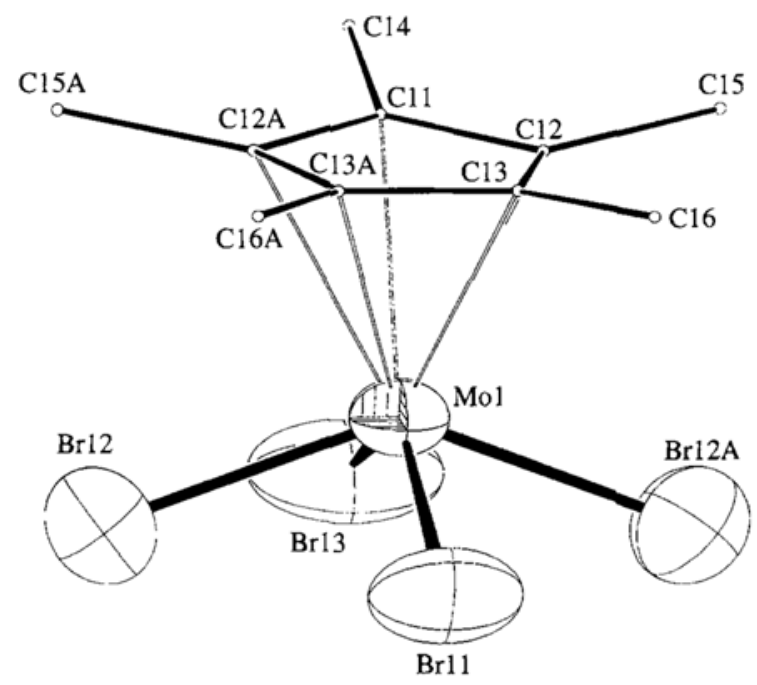

Fig. 3. Crystal structure of 3 (ORTEP). The two crystallographically independent anions $3^{-}$have identical structural parameters. Selected bond lengths $[\AA]$ and angles $\left[^{\circ}\right]$ (averaged over all chemically equivalent groups of atoms): $\mathbf{3}^{-}$: Mo-Br 2.62(4), Br-Mo-Br (cis) 81.8(4), Br-Mo-Br (trans), 136(3). 3: $\mathrm{Mo}-\mathrm{Br}$ 2.48(3), Br-Mo-Br (cis) 82.8(4), Br-Mo-Br (trans) 138(2).

different in the three mononuclear complexes; however, the $\mathrm{Mo}-\mathrm{Br}$ distances at atom Mo1 are significantly shorter (average 2.48(4) $\AA$ ) than those at atoms Mo4 and Mo5 (Mo4: range 2.595(6)-2.616(9) $\AA$; Mo5: range 2.591(6)$2.721(8) \AA$ ). This reflects the stronger $\pi$ acidity of the neutral $\mathrm{d}^{1}$ complex $\left[\mathrm{Cp} * \mathrm{MoBr}_{4}\right]$ and allows us to identify Mo1 as the central atom in as 3. An ORTEP representation of the unit 


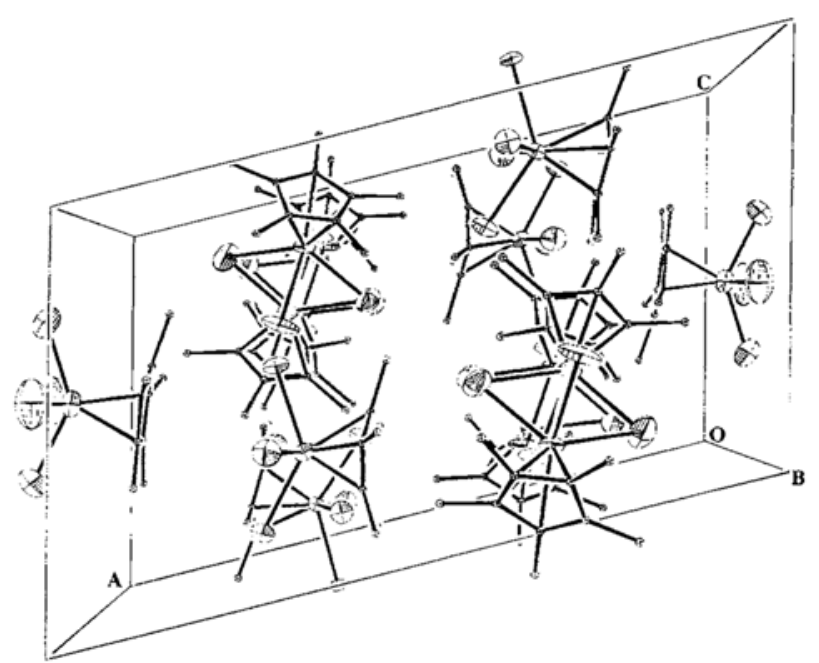

Fig. 4. Unit cell of 1 (ORTEP).

cell of 1 giving the relative orientations of all three constituents to each other is shown in Figure 4.

The formation of 1 from 2 and $\mathrm{Br}_{2}$ can be understood in terms of their redox behaviors (see Fig. 2). Initially, $\mathrm{Br}_{2}$ oxides 2 to give the benzene-insoluble salt $\mathbf{5}$, which contains the cation $2^{+}$and a mixture of $\mathrm{Br}^{-}$and $\mathrm{Br}_{3}^{-}$as discussed above. During the crystallization from $\mathrm{CH}_{2} \mathrm{Cl}_{2}, \mathrm{Br}^{-}$can add to $2^{+}$ to give the neutral adduct 2- $\mathrm{Br}$. Oxidation with $\mathrm{Br}_{3}^{-}$and subsequent reaction with $\mathrm{Br}^{-}$via the possible intermediate $\left[\mathrm{Cp}^{*} \mathrm{MoBr}_{3}\right]_{2}$ will give the paramagnetic anion $3^{-}$(Scheme 1).

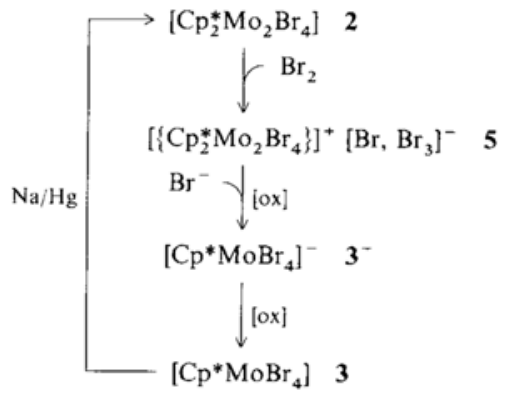

Scheme 1. $[o x]=$ oxidation.

Any residual $\mathrm{Br}_{3}^{-}$, according to the electrochemical study (Fig. 2), would be capable of oxidizing $3^{-}$to give neutral 3 . Thus, considering the composition of compound $\mathbf{5}$, a mixture of $2,3^{-}$and 3 in a mol ratio of $1: 1: 2.1$ should be produced in solution. But a mixture of the three components in a mol ratio of $2: 2: 1$ is found in the crystal, presumably because a compound with this particular combination is the least soluble material in the solvent combination used for crystallization. Treatment of compound 5 with excess $\mathrm{Br}^{-}$ eventually leads to a product with a single broad ${ }^{1} \mathrm{H}$ NMR resonance at $\delta=-19.5$, which is attributed to $3^{-}$in agreement with the reactions depicted in Scheme 1. Figure 2 indicates that the two neutral complexes $\mathbf{3}$ and $\mathbf{2}$ are not stable with respect to electron transfer. In fact, mixing a stoichiometric amount of $\mathbf{3}$ and $\mathbf{2}$ produces a solution that exhibits the ${ }^{1} \mathrm{H}$ NMR resonances of the cation $2^{+}$and the $\mathrm{Mo}^{\mathrm{IV}}$ anion $3^{-}$.
Currently, efforts are under way to isolate $\left[\left\{\mathrm{Cp} * \mathrm{MoBr}_{3}\right\}_{2}\right]$ (4), which requires reaction conditions under which free bromide ion cannot exist.

\section{Experimental Procedure}

3: $\left[\mathrm{Cp}^{*} \mathrm{MoBr}_{4}\right]$ was prepared by a procedure similar to that described for $\left[\mathrm{Cp}^{\prime} \mathrm{MoBr}_{4}\right][3]:\left[\left\{\mathrm{Cp}^{*} \mathrm{Mo}(\mathrm{CO})_{3}\right\}_{2}\right](1.03 \mathrm{~g} .1 .62 \mathrm{mmol})$ was dissolved in $\mathrm{CH}_{2} \mathrm{Cl}_{2}$ $(20 \mathrm{~mL})$. and the red-orange solution was transferred by cannula to a slurry of yellow $\mathrm{PBr},(2.80 \mathrm{~g}, 6.52 \mathrm{mmol})$ in $\mathrm{CH}_{2} \mathrm{Cl}_{2}(20 \mathrm{~mL})$. Vigorous gas evolution indicated an immediate reaction. The reaction mixture was then refluxed approximatly $12 \mathrm{~h}$. The solution was reduced in volume to approximately $30 \mathrm{~mL}$. The almost black precipitate was collected by filtration, washed with cold $\mathrm{CH}_{2} \mathrm{Cl}_{2}(3 \times 5 \mathrm{~mL})$ and dried under vaccum to yield $1.56 \mathrm{~g}(87 \%)$ of 3 . Correct elemental analysis (C, $\mathrm{H}, \mathrm{Br}$ ).

2: Compound $3(3.427 \mathrm{~g} .6 .22 \mathrm{mmol})$ was placed in a Schlenk tube containing freshly prepared sodium amalgam $(311 \mathrm{mg}$ of $\mathrm{Na}, 13.5 \mathrm{mmol}$ in $31 \mathrm{~g} \mathrm{Hg}$ ). Toluene $(40 \mathrm{~mL})$ was added, and the dark suspension was allowed to stir at room temperature $\left(21^{\mathrm{C}} \mathrm{C}\right)$ for about $12 \mathrm{~h}$, during which the solution developed a tan brown color. The reaction mixture was filtered and the precipitate washed with toluene until the washings were colorless $(4 \times 20 \mathrm{~mL})$. The combined filtrates were reduced in volume and cooled to $-20^{\circ} \mathrm{C}$ to yield $2.18 \mathrm{~g}(90 \%)$ of 2. ${ }^{\mathrm{I}} \mathrm{HNMR}\left(200 \mathrm{MHz}, \mathrm{CDCl}_{3}, 25^{\circ} \mathrm{C}\right): \delta=1.93$ (s). Cyclic voltammogram $\left(\mathrm{CH}_{2} \mathrm{Cl}_{2} / 0.1 \mathrm{M} n \mathrm{Bu}_{4} \mathrm{NPF}_{6}, E[\mathrm{~V}]\right.$ vs. $\left.\mathrm{Cp}_{2} \mathrm{Fe} / \mathrm{Cp}_{2} \mathrm{Fe}^{+}\right):-0.30\left(\left[\mathrm{Cp}^{*} \mathrm{MoBr}_{2}\right\}_{2}\right] /$ $\left.\left[\left\{\mathrm{Cp}^{*} \mathrm{MoBr}_{2}\right\}_{2}\right]^{+}\right),+0.73\left(\left[\left\{\mathrm{Cp}^{*} \mathrm{MoBr}_{2}\right\}_{2}\right]^{+} /\left[\left\{\mathrm{Cp}^{*} \mathrm{MoBr}_{2}\right\}_{2}\right]^{2+}\right)$. Correct elemental analysis $(\mathrm{C}, \mathrm{H})$.

1: Compound 2 (538 mg, $0.69 \mathrm{mmol})$ was dissolved in benzene $(10 \mathrm{~mL})$. A solution of $\mathrm{Br}_{2}(35 \mu \mathrm{L}, 0.69 \mathrm{mmol})$ in benzene $(5 \mathrm{~mL})$ was added, causing the immediate formation of a red precipitate. The product was collected by filtration, washed with $n$-heptane, and dried under vacuum $(381 \mathrm{mg}) .{ }^{1} \mathrm{H}$ NMR $\left(200 \mathrm{MHz} \mathrm{CDCl}_{3}, 25^{\circ} \mathrm{C}\right): \delta=4.3\left(\mathrm{br}, w_{1 / 2}=120 \mathrm{~Hz}\right)$. Recrystallization of this product from $\mathrm{CH}_{2} \mathrm{Cl}_{2} / n$-heptane yielded 1 as dark red plates. ${ }^{1} \mathrm{HNMR}$ $\left(200 \mathrm{MHz} . \mathrm{CDCl}_{3}, 25 \mathrm{C}\right): \delta=4.2\left(w_{1 / 2}=120 \mathrm{~Hz}\right),-19.5\left(w_{1 / 2}=137 \mathrm{~Hz}\right)$. One of these crystals was used in the crystallographic investigation.

Reaction between 3 and 2 : To a solid mixture of 2 (17 mg; $0.022 \mathrm{mmol})$ and 3 (23 mg; $0.042 \mathrm{mmol}$ ) in a Schlenk tube, was added $\mathrm{CDCl}_{3}(1 \mathrm{~mL})$. The resulting orange-brown solution was transferred to an NMR tube ( 5 mm o.d.). ${ }^{1} \mathrm{H}$ NMR $\left(200 \mathrm{MHz}, \mathrm{CDCl}_{3}, 25^{\circ} \mathrm{C}\right): \delta=4.13\left(w_{1: 2}=85 \mathrm{~Hz}\right),-19.53\left(u_{1 / 2}=137 \mathrm{~Hz}\right)$.

Received: April 3.1993 [Z 5977 IE] German version: Angew: Chem. 1993, 105, 1506

[1] R. Poli, Chem. Rev. 1991, 91, 509-551.

[2] R. Poli, M. A. Kelland. J. Organomet. Chem. 1991, 419, 127-136.

[3] M. L. H. Green, J. D. Hubert. P. Mountford, J. Chem. Soc. Dalton Trans. $1990,3793-3800$

[4] C. Saadeh, S. B. Colbran, D. C. Craig, A. D. Rae, Organometallics 1993, 12. $133-139$

[5] a) M. L. H. Green. A. Izquierdo, J. J. Martin-Polo, V. S. B. Mtetwa, K. Prout. J. Chem. Soc., Chem. Commun. 1983, 538-540; b) R. Poli, J. C. Gordon, J. U. Desai, A. L. Rheingold, ibid. 1991, 1518-1520.

[6] Crystal structure analysis of $2: \mathrm{C}_{20} \mathrm{H}_{30} \mathrm{Br}_{4} \mathrm{Mo}_{2}, M=782.0$, monoclinic, $a=8.356(1) . \quad b=32.272(5), \quad c=13.972(2) \AA, \quad \beta=98.17(1)^{\circ}, \quad V=$ $3729.3(10) \AA^{3}$, space group $P 2_{1} / n, Z=6, \mu\left(\mathrm{Mo}_{\mathrm{K}}\right)=73.60 \mathrm{~cm}^{-1} . \varrho_{\text {calcd }}=$ $2.088 \mathrm{~g} \mathrm{~cm}^{-3}$. independent reflections (total reflections) 5741 (6407), 2715 reflections $\left(F_{0}>4 \sigma\left(F_{0}\right)\right), R=0.0614\left(R_{w}=0.0755\right)$ [8].

[7] M. Mastragostino. S. Valcher, P. Lazzari, J. Electroanal. Chem. Interfacial Electrochem. 1981, 126.189-198.

[8] Crystal structure analysis of $1: \mathrm{C}_{84} \mathrm{H}_{13}{ }_{7} \mathrm{Br}_{20} \mathrm{Mo}_{7}, M=3416.67$, monoclinic. $a=20.218(6), b=23.332(5), \quad c=12.093(2) \AA, \quad \beta=104.76(2)^{\circ}, \quad V=$ $5516(2) \AA^{3}$. space group $P 2_{1} / m, Z=2, \mu\left(\mathrm{Mo}_{\mathrm{K} z}\right)=84.62 \mathrm{~cm}^{-1}, \varrho_{\text {calcd }}=$ $2.06 \mathrm{~g} \mathrm{~cm}^{-3}$, independent reflections (total reflections) 7414 (7657), 2172 reflections $\left(\left|F_{\mathrm{o}}\right|^{2}>3 \sigma\left|F_{\mathrm{o}}\right|^{2}\right), 365$ parameters refined, $R=0.089\left(R_{\mathrm{w}}=\right.$ $0.094)$. The reflections were measured on an Enraf-Nonius CAD4 diffractometer with $\mathrm{Mo}_{K_{x}}$ radiation $(\lambda=0.71073 \AA$ ) by using the $\omega-2 \theta$ scan method. The structure of 1 was solved using the TEXSAN program package. The positions of all non-hydrogen atoms were determined from difference Fourier maps. The $\mathrm{Mo}$ and $\mathrm{Br}$ atoms were refined anisotropically; the $\mathrm{C}$ atoms were refined isotropically. All $\mathrm{Cp} *$ ligands were restrained to ideal pentagons with $\mathrm{C}-\mathrm{C}($ ring $)=1.42(1) \AA$ and $\mathrm{C}-\mathrm{C}(\mathrm{Me})=1.56 \AA$ and the interstitial heptane molecule restrained to $\mathrm{C}-\mathrm{C}=1.54(2) \AA$ (SHELX76). Some of the $\mathrm{Cp}^{*}$ methyl carbon atoms refined with very a high thermal parameter, indicating fast rotation of the rings about the metal-ring axis and/or partial disorder of the rings. Further details of the crystal structure can be obtained upon request from the Director of the Cambridge Crystallographic Data Centre, University Chemical Laboratory, 12 Union Road. GB-Cambridge CB2 1EZ (UK), on quoting the full journal citation.

[9] J. C. Green, M. L. H. Green, P. Mountford, M. J. Parkington, J. Chem. Soc. Dalton Trans. 1990, 3407-3418. 